\title{
REKONSTRUKSI FILSAFAT PENDIDIKAN ISLAM (Mengembalikan Tujuan Pendidikan Islam Berbasis Tujuan Penciptaan dan Tujuan Risalah)
}

\author{
Hikmatul Mustaghfiroh \\ COIN (Conge Institute), Jawa Tengah, Indonesia. \\ hikmatulmus@yahoo.co.id
}

\begin{abstract}
Abstrak
Kajian ini bertujuan untuk mendeskripsikan rekonstruksi filsafat pendidikan Islam sesuai tujuan penciptaan dan tujuan risalah. Pendekatan dalam peneltian ini adalah penelitian kepustakaan. Hasil penelitian ini adalah bahwa pada hakekatnya, Islam diturunkan ke dunia ini tidak lain adalah untuk memberikan tuntunan kebahagian bagi ummat manusia. Eksistesi Islam adalah rahmatan li al-'álamin, penebar kedamaian bagi semesta alam. Yang secara teologis kemudian kita pahami sebagai tujuan risalah Islam. Filsafat Pendidikan Islam adalah landasan filosofis dalam implementasi pendidikan Islam. Dalam hal ini, filsafat pendidikan Islam harus berorientasi pada dua hal, yakni tujuan penciptaan manusia, yakni sebagai hamba dan sebagai khalifah. Kedua, tujuan risalah islam, yakni menjadi rahmat bagi semesta dan menyempurnakan akhlak yang mulia.
\end{abstract}

Kata Kunci: rekonstruksi, filsafat pendidikan, Islam, tujuan risalah

\section{Abstract}

THE RECONSTRUCTION OF ISLAMIC EDUCATION PHILOSOPHY (RESTORING THE ISLAMIC EDUCATION OBJECTIVE BASED ON THE CREATION AND PURPOSE TREATISE). This study aims to describe the reconstruction of Islamic education philosophy in accordance with the purpose of treatise creation and purpose. The approach of this study is library research. 
Hikmatul Mustaghfiroh

The result of this study is that in fact, Islam was revealed to the world is none other than to provide the happiness guidance for Moslems. The existence of Islam is rahmatan li al-'alamin, the diffuser of peace for the Earth. That theologically we understand as the Islamic treatise destination. Islamic education philosophy is the philosophical grounding in Islamic education implementation. In this case, Islamic education philosophy must be oriented in two ways, i.e. the purpose of the human creation, i.e. as a servant and as the Caliph. Second, the purpose of the Islamic treatise, i.e. be a mercy to the universe and improve the noble morals.

Keywords: reconstruction, islam, education, philosophy, the goal of the treatise

\section{A. Pendahuluan}

Berbagai fenomena sosial yang belakangan ini marak terjadi, mulai dari tawuran, konflik SARA hingga fenomena korupsi, seakan menampar eksistensi pendidikan kita. Meskipun pendidikan bukan satu-satunya faktor penyebab fenomena tersebut, namun harus diakui bahwa pendidikan mempunyai andil besar dalam pembangunan karakter manusia. Banyak pihak yang kemudian bertanya, apakah ada yang salah dengan pendidikan kita?

Pendidikan merupakan faktor utama pembangunan potensi manusia. Melalui pendidikan manusia akan mampu melaksanakan fungsi dan tanggung jawabnya sebagai manusia. Di sini pendidikan harus diupayakan sedemikian rupa untuk mampu menghasilkan output pendidikan yang sesuai dengan fitrah kemanusiaan.

Apalagi dalam konteks pendidikan Islam, maka ada beban sosial yang harus dipikul oleh pendidikan Islam ini. Sebagai penjaga gawang moralitas muslim, pendidikan islam dituntut untuk mampu membekali output pendidikan dalam penerapan karakter dan moralitas keislaman yang mulia. Sehingga, tanpa bermaksud melakukan simplifikasi, keberhasilan pendidikan islam pada dasarnya bisa diukur dari karakter dan prilaku muslim, yang merupakan output pendidiakn Islam.

Berbagai macam problematika pendidikan yang selama ini selalu ada, mengisyaratkan bahwa pendidikan merupakan proses dinamis yang berkesinambungan. Ini berarti bahwa permasalahan 
dalam pendidikan adalah sebuah keniscayaan, dan untuk mengatasinya, diperlukan landasan yang kuat yang mampu menjadi pijakan dalam sebuah keputusan. Salah satu landasan pendidikan yang menjadi pijakan tersebut adalah landasan filsafat.

Sebagaimana yang kita ketahui bersama, bahwa filsafat merupakan induk pengetahuan. Semua ilmu, pada dasarnya lahir dari kajian filsafat. Demikian juga dengan pendidikan, sebagai bagain dari ragam ilmu, pendidikan dan pendidikan islam mengacu pada landasan filosofis yang jelas. Sebagaimana filsafat, pada implementasinya, filsafatpendidikan mempunyai ragam yang banyak, berdasar pada filsafat sebagai induknya.

Aktivitas kependidikan Islam di Indonesia, pada dasarnya sudah berlangsung dan berkembang sejak lama. Hal ini dapat dilihat dari fenomena tumbuh kembangnya program dan praktek pendidikan Islam yang dilaksanakan di Nusantara; Pesantren, Madrasah, pendidikan umum yang bernafaskan Islam, dan beberapa model pendidikan baik in formal maupun nonformal lainnya adalah manifestasi dari pendidikan Islam tersebut. Dan bahkan secara umum pendidikan Islam itu ada sejak lahirnya islam itu sendiri. Awal pendidikan islam adalah pengajaran Alquran yang dilakukan oleh Muhammad kepada para sahabatnya (Darwis, 2006: 4).

Fenomena tersebut menggaris bawahi adanya pemikiran tentang pengembangan pendidikan Islam diIndonesia dalam berbagai jenis dan bentuknya. Hanya saja, dikalangan para ahli masih terdapat pendapat-pendapat yang kontroversial, terutama menyangkut kekokohan landasan filosofisnya. Disatu pihak ada yang menyatakan bahwa adanya kegiatan pendidikan Islam, sistem pendidikan Islam yang memiliki ciri-ciri tertentu, menunjukkan adanya bangunan filosofis yang kokoh dari program dan praktek pendidikan Islam.

Landasan filosofi pendidikan Islam yang kokoh dan mendasar, pada akhirnya akan mampu menjadi pijakan dalam setiap keputusan pendidikan dan pemecahan permasalahannya. Sampai sini, filsafat pendidikan Islam harus mampu menjadi landasarn dalam kontekstualisasi pendidikan secara umum. Jika fenomena moralitas muslim saat ini menunjukkan derajat yang sangat memperihatinkan, itu berarti ada yang kurang "pas"dalam filsafat pendidikan. Sehingga tulisan ini bermaksud melakukan rekonstruksi filsafat pendidikan 
Islam dan mengarahkannya pada tujuan risalah Islam. Hal ini penting, dalam rangka menghadirkan kembali orientasi pendidikan Islam sesuai dengan tujuan Islam itu sendiri. Hingga pada akhirnya, tujuan pendidikan akan mampu mewujudkan tujuan risalah yakni membangun rahmat bagi semesta alam, diawali dengan membangun filsafat Islam yang relevan.

\section{B. Pembahasan}

\section{Konsep Dasar Filsafat Pendidikan Islam}

Berbicara tentang Filsafat, maka ada beberapa terminologi yang kiranya harus dipahami. Berikut akan dipaparkan secara singkat beberapa term yang berhubungan dengan landasan filosofis pendidikan dan pendidikan Islam.

\section{a. Filsafat}

Secara etimologi (bahasa), filsafat berasal dari bahasa Yunani, yaitu gabungan dari akta philo yang artinya cinta, suka dan shopia yang berarti kebijaksanaan, kebenaran, hikmah (wisdom), atau pengetahuan yang mendalam. Sehingga secara mudah, filsafat dapat diartikan sebagai "cinta akan kebenaran" (Jalaluddin, 1996: 7). Sedang menurut istilah (terminologi), filsafat adalah berfikir secara sistematis, radikal dan universal untuk mengetahui tentang hakikat sesuatu yang ada. Dengan kata lain, filsafat adalah ilmu yang mempelajari dengan sungguh-sungguh tentang hakikat kebenaran segala sesuatu (Mufid, 2008: 8).

Filsafat dapat diartikan sebagai ilmu yang berusaha untuk memahami semua hal yang timbul di dalam keseluruhan ruang lingkup pengalaman manusia. Hal ini diharapkan agar manusia dapat mengerti dan mempunyai pandangan menyeluruh dan sistematis mengenai alam semesta dan dirinya sendiri. Dalam hal ini, filsafat berhubungan degan upaya manusia untuk mernjawab pertanyaan pertanyaan yang timbul dalam pengalaman kehidupannya.

Dalam perkembangannya filsafat mampu mengantarkan manusia sebagai "insan yang berfikir", yang mampu mengatasi permasalahan kehidupan dengan pemikirannya. Melalui filsafat, berbagai disiplin ilmu lahir. Sehingga filsafat sering disebut sebagai induk ilmu pengetahuan. Dalam membaca kenyataan yang ada, 
aliran-aliran filsafat pun muncul, berdasar pada subjektifitas yang filosof yang membentuknya.

\section{b. Ilmu dan Ilmu Pendidikan}

Kata "ilmu" dalam bahasa Indonesia berasal dari bahasa Arab ilm yang merupakan kata jadian dari 'alima yang berarti "tahu” atau "mengetahui". Ilmu dalam penjelajahannya memiliki keterbatasan yang terletak pada fungsi ilmu itu sendiri dalam kehidupan manusia. Ilmu berfungsi sebagai alat bantu manusia dalam mengatasi masalah sehari- hari.

Pada dasarnya semua ilmu bertujuan untuk menemukan hukum, norma dan kaidah yang berlaku umum untuk semua, disamping kekecualian dan kekhasan serta perbedaan yang ada pada setiap objek yang diamatinya. Melalui ilmu, orang mengenal lingkungan dandirinya serta mengenal Dzat Yang Maha Menciptakan. Ilmu tidak bisa berdiri sendiri, melainkan saling memiliki hubungan dan ketergantungan dengan ilmu yang lain. Pendekatan terpadu adalah bagian dari paradigma ilmu dari segi perspektif pemikiran Islam. Sedangkan ilmu pengetahuan adalah hasil usaha pemahaman manusia yang disusun dalam suatu sistem yang meliputi kenyataan, struktur, membedakan bagian-bagian dan hukum-hukum tentang objek kajian yang diteliti yaitu alam, manusia dan agama, sejauh yang dapat dijangkau oleh akal manusia dengan dibantu panca indera yang kebenarannya diuji secara empiris, riset dan eksperimental (Muhadjir, 2001: 3). Terminologi "ilmu dan ilmu Islam" ini perlu dicermati terlebih dahulu sejak awal, sebab hal itu dapat memberikan pengertian ganda. Jujun S. Suriasumantri dalam Mas'ud membedakan antara ilmu dan pengetahuan. Menurutnya ilmu menelaah pengetahuan secara menyeluruh mulai dari pra sampai pasca pengalaman (Mas'ud, 2001: 9).

Berdasarkan batasan di atas dapat dielaborasikan, bahwa terminologi ilmu menunjuk pada kumpulan pengetahuan yang tersusun secara sistematis dan dihimpun melalui teknik pengamatan yang secara obyektif. Namun sebenarnya "ilmu" dan "pengetahuan" hanya merupakan produk dari suatu proses atauaktifitas. Perlu ditegaskan bahwa konsep ilmu dalam tradisi Islam sangat berbeda dengan konsep ilmu dalam tradisi barat. Menurut paradigma filsafat 
ilmu barat mengenal tiga aliran yaitu rasionalisme, empirisme dan realisme, sedangkan filsafat ilmu dalam Islam mengenal tiga aliran besarnya itu bayani,irfani dan burhani (Mufid, 2008: 9).

Menurut Khun, ilmu (sains) dibangun oleh sebuah paradigma yang melatarbelakanginya. Dan ilmu berkembang sesuai dengan "setting" paradigma tersebut. Pada awalnya, ilmu terbangun dari sifat ilmu yang normal. Namun pada perjalannya akan mengalami anomali, krisis dan akhirnya harus di revolusi. Untuk merevolusi menjadi ilmu yang normal (kembali) diperlukan sebuah paradigma (Khun, 2000: 43). Dari sini, untuk membangun sebuah ilmu (pendidikan Islam) yang "normal" diperlukan sebuah paradigma yang kokoh dam handal. Karena paradigma tersebut akan mampu menuntun ilmu sesuai dengan realitas riang waktu yang ada.

Di sisi lain, Ilmu Pendidikan adalah bagian dari disipiln ilmu yang ada. Dalam hal ini, ilmu pendidikan adalah ilmu yang membahas tentang pendidikan, beserta ikhwal yang terkait dengannya. Sebagai salah satu disiplin ilmu, ilmu pedidikan mempunyai obyek material yang sama dengan disiplin ilmu lain, yakni manusia dan lingkungan. Namun dalam hal objek formal, maka ilmu pendidikan mengkhususkan diri pada usaha-usaha yang dilakukan dalam rangka mengantarkan manusia menjadi manusia yang sempurna. Proses pembelajaran adalah fokus utama dalam objek forma ini. Meskipun tidak mengesampingkan faktor-foktor yang terkait dalam usaha tersebut.

\section{c. Filsafat Pendidikan}

John Dewey sebagaimana dikutip Imam Barnadib, mengartikan filsafat pendidikan sebagai teori umum dari pendidikan, landasan dari semua pemikiran umum mengenai pendidikan. Barnadib sendiri mengartikan filsafat pendidikan sebagai ilmu yang pada hakikatnya merupakan jawaban dari pertayaan-pertanyaan dalam lapangan pendidikan dan merupakan penerapan suatu analisis filosofis terhadap pendidikan (Barnadib, 1986: 9).

Al-Syaibāny dalam Jalaluddin, melihat falsafat pendidikan adalah pelaksanaan pandangan falsafat dan kaidah falsafah dalam pengalaman manusia yang disebut pendidikan. Secara rinci dikemukakan bahwa falsafat pendidikan merupakan usaha untuk 
mencari konsep-konsep diantara gejala yang bermaacam- macam meliputi: (a) proses pendidikan sebagai rancangan yang terpadu dan meyeluruh; (b) menjelaskan berbagai makna yang mendasar tentang segala istilah pendidikan; dan (c) pokok-pokok yang menjadi dasar dari konsep pendidikan dalam kaitannya dengan bidang kehidupan manusia (Jalaluddin, 1996: 12).

\section{d. ilsafat pendidikan Islam}

Filsafat Pendidikan Islam secara pemaknaan, tidak jauh berbeda dengan filsafat pendidikan. Disisni yang paling menonjol dalam filsafat pendidikan Islam adalah karakteristik al-Qur'an dan sunnah sebagai dasar sekaligus sumber.

Secara istilah ada beberapa pengertian tentang filsafat pendidikan Islam. Muzayyin Arifin, misalnya mengatakan bahwa filsafat pendidikan Islam pada hakikatnya adalah konsep berfikir tentang hakikat kemampuan manusia untuk dibina dan dikembangkan serta dibimbing menjadi manusia muslim yang seluruh pribadinya dijiwai oleh ajaran Islam (Arifin, 1994: 38). Definisi ini memberi kesan bahwa filsafat pendidikan Islam memiliki makna yang sama dengan filsafat pendidikan pada umumnya. Dalam arti bahwa filsafat Islam mengkaji tentang berbagai masalah manusia sebagai subjek dan objek pendidikan, kurikulum, metode, lingkungan, guru, dan lain sebagainya.

Perbedaan filsafat pendidikan Islam dengan filsafat pendidikan pada umumnya adalah bahwa di dalam filsafat pendidikan Islam, semua masalah kependidikan tersebut selalu didasarkan pada ajaran Islam yang bersumberkan al-Qur'an dan Hadits. Dengan kata lain bahwa kata Islam yang mengiringi kata falsafat pendidikan ini menjadi sifat, yakni sifat dari filsafat pendidikan tersebut.

Dalam hubungan ini Ahmad D. Marimba mengatakan bahwa filsafat pendidikan Islam bukanlah filsafat pendidikan tanpa batas. Selanjutnya ketika ia mengomentari kata 'radikal' yang menjadi salah satu ciri berpikir filsafat mengatakan bahwa pandangan ini keliru. Radikal bukan berarti tanpa batas. Tidak ada di dunia ini disebut tanpa batas, dan bukankah dengan menyatakan bahwa seorang muslim yang telah menyalini isi keimanannya, akan mengetahui di mana batas-batas pikiran (akal) dapat dipergunakan, dan jika 
ia berfikir, berfilsafat mensyukuri nikmat Allah, berarti ia radikal (konsekuen) dalam batas-batas itu.

\section{e. Hakikat dan Fungsi}

Pada hakikatnya, pendidikan Islam adalah suatu proses yang berlangsung kontiniu/berkesinambungan, berdasarkan hal ini, maka tugas dan fungsi yang diemban oleh pendidikan Islam adalah pendidikan manusia seutuhnya dan berlangsung sepanjang hayat. Konsep ini bermakna bahwa tugas dan fungsi pendidikan memiliki sasaran pada peserta didik yang senantiasa tumbuh berkembang secara dinamis, mulai dari kandungan sampai hayatnya.

Sedangkan pengertian pendidikan Islam itu sendiri adalah usaha yang lebih khusus ditekankan untuk mengembangkan fitrah keberagamaan subjek didik agar lebih mampu memahami, menghayati dan mengamalkan ajaran- ajaran Islam. Definisi ini sebagaimana dicetuskan dalam Konferensi dunia Pertama tentang Pendidikan Islam tahun 1977 (Ahmadi, 2005: 29). Secara umum fungsi pendidikan Islam dalam hal ini adalah memelihara dan mengembangkan fitrah dan sumber daya manusia menuju terbentukkan manusia seutuhnya (insan kamil), yakni manusia berkualitas sesuai dengan pandangan islam. Secara umum tugas pendidikan Islam adalah membimbing dan mengarahkan pertumbuhan dan perkembangan peserta didik dari tahap ke tahap sampai ke titik kemampuan optimal

\section{f. Dasar dan Tujuan}

Dasar dan tujuan filsafat pendidikan islam pada hakikatnya identik dengan dasar dan tujuan ajaran Islam atau tepatnya tujuan Islam itu sendiri. Dari kedua sumber ini kemudian timbul pemikiran-pemikiran mengenai masalah-masalah keislaman dala $\mathrm{m}$ berbagai aspek, termasuk filsafat pendidikan (Said,1996: 19). Tujuan akhir pendidikan muslim terletak pada perwujudan ketundukan yang sempurna kepada Allah, baik secara pribadi, komunitas, maupun keseluruhan.

Dasar kajian filsafat pendidikan tidak lain adalah mengenai pencipta (Allah), ciptaannya (makhluk), hubungan antara ciptaan dan pencipta, serta hubungan antara sesama ciptaan-Nya, dan utusan yang menyampaikan risalah (rasul). Sehingga pada dasarnya obyek kajian filasafat pendidikan Islam adalah luas dan meliputi seluruh 
alam semesta bahkan mengenai tentang Tuhan. Dari sini, maka pedidikan Islam yang merupakan produk filsafat pendidikan Islam, harus mampu mengkaji semua aspek kehidupa manusia, di samping nilai kertahuidan dan kerasulan.

\section{Pendidikan Islam Berbasis Tujuan Risalah}

Pada hakekatnya, Islam diturunkan ke dunia ini tidak lain adalah untuk memberikan tuntunan kebahagian bagi ummat manusia. Islam merupakan agama pamungkas, yang dibawa oleh Muhammad sebagai penyempurna agama "Islam" terdahulu. Berbeda dengan ajaran "Islam" terdahulu, ajaran Islam Muhammad lebih berwatak humanis dan apresiatif terhadap hak-hak kemanusiaan. Sehingga Islam yang terakhir inilah, yang di harapkan mampu menjadi "lampu penerang" bagi ummat manusia. Di sini, eksistesi Islam adalah rahmatan li al-alamin, penebar kedamaian bagi semestaalam. Yang secara teologis kemudian kita pahami sebagai tujuan risalah Islam.

Konsep rahmatan li al-'alamin dalam hal ini menjadi landasan bagi segala bangunan keislaman yang disandarkan pada Islam. Termasuk dalam hal ini adalah pendidikan Islam. Pendidikan islam yang merupakan bagian dari pelestarian ajaran Islam harus sesuai dan bersumbu pada nilai-nilai dasar Islam. Selain itu, tujuan pendidikan Islam juga harus berorientasi pada tujuan penciptaan. Mengingat, manusia diciptakan Allah ke dunia ini mempunyai misi religus-sosial. Jika pendidikan dipahami sebagai media untuk membangun dan mengembangkan potensi manusia, maka pembangunan karakter dasar tersebut harus selalu berjalan pada jalur tujuan penciptaan manusia.

Jika semua landasan tersebut diurai lebih rinci, maka hakikat pendidikan islam harus berbasis pada hal-hal sebagai berikut:

\section{a. Membangun nilai kehambaan}

Manusia diciptakan oleh Allah mempunyai visi penghambaan yang sejati. Artinya, hakekat diciptakannya manusia tidaklainadalah untuk menyembah, mengabdi dan menghamba kepada-Nya. Sebagaimana termaktub dalam Q.S. al- Dzariyat ayat 56 sebagai berikut: 
Hikmatul Mustaghfiroh

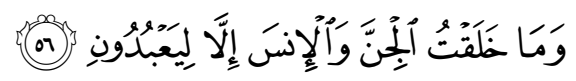

Dan Aku tidak menciptakan jin dan manusia melainkan supaya mereka mengabdi kepada-Ku. (Q.S.51: 56)

Ayat ini menegaskan bahwa baik jin maupun manusia diciptakan semata-mata untuk menyembah kepada Allah. Sehingga kehidupan manusia didunia merupakan wahana untuk mengabdi dan menyerahkan diri sepenuhnya kepada-Nya. Hal ini mengisyaratkan bahwa manusia harus membangun komunikasi vertikal, yakni eksistensi diri sebagai hamba, kepada realitas maha mutlak sang Khaliq. Dalam konteks pendidikan Islam, pendidikan tidak ubah merupakan wahana pengembangan kesalehan individu manusia kepadaTuhannya. Pendidikan harus semakin menyadarkanakan hakekat penciptaan sebagai hamba,yang senantiasa beribadah untuk allah SWT. Output pendidikan Islam bisa dipahami untuk mencetak jati diri seorang 'abid yang senantiasa beribadah dan pasrah kepada Nya. Tujuan oendidikan islam dalam ranah ini adalah melahirkan pribadi-pribadi muslim yang beriman dan bertaqwa kepada Allah.

Pemahaman penghambaan ini juga menyadarkan manusia bahwa manusia mempunyai keterbatasan. Sebagai hamba (budak) manusia tidak mempunyai kehendak bebas, ia berada dalam kungkungan aturan untuk mengabdi kepada-Nya. Sehingga semakin cerdas seorang muslim, ia semakin sadar akan keterbatasan dan posisi sebagai makhluk yang lemah. Derajat kepemilikan ilmu yang tinggi, hanya akan menjadikan diri dekat dan patuh terhadap ajaran dan nilai agama.

\section{b. Menjadi wakil Tuhan}

Selain mempunyai misi kehambaan, manusia juga didaulat oleh Allah untuk menjadi wakil-Nya di muka bumi. Hal ini sebagaimana status khalifah allah fi al-ardhi yang melekat pada diri manusia. Sebagai wakil Allah, manusia mempunyai misi untuk melestarikan dan menjaga alam semesta dari segala bentuk kerusakan. Sebaliknya, manusia mempunyai agenda pentuk untuk menjaga alam, dengan segala potensi yang ada di dalamnya. Sebagaimana firman Allah dalam surat al-Baqarah ayat 30 berikut:

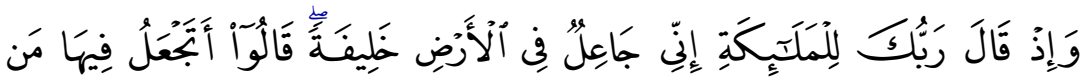




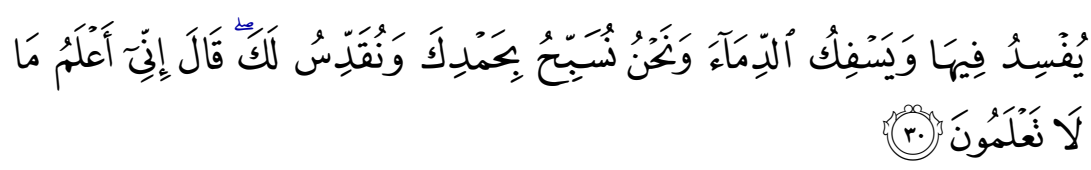

"Dan Ingatlah ketika Tuhanmu berfirman kepada para malaikat: "Sesungguhnya Aku hendak menjadikan seorang khalifah di muka bumi." Mereka berkata: "Mengapa Engkau hendak menjadikan (khalifah) dibumi itu orang yang akan membuat kerusakan padanya dan menumpahkan darah, padahal kami senantiasa bertasbih dengan memuji Engkau dan mensucikan Engkau?"Tuhan berfirman: "Sesungguhnya Aku mengetahui apa yang tidak kamu ketahui."(Q.S. Al-Baqarah: 30$)$.

Ayat di atas menandaskan bahwa tujuan manusia diciptakan adalah sebagai khalifah. Khalifah secara bahasa berarti pengganti. Sebagai khalifah, manusia hakekatnya adalah pengganti Allah di bumi. Sehingga, manusia harus mampu memakmurkan bumi dan mencerminkan sebagai pihak yang diwakili, yakni Allah. Meskipun pada awalnya, para malaikat meragukan dan pesimis terhadap manusia, karena dua tabiat dasarnya, yaitu perusak ( $y u f s i d u)$ dan suka berperang (yusfiku). Namun Allah dengan segala kemahatahuan-Nya menegaskan untuk tetap menciptakan manusia dimuka bumi ini sebagai wakil atau pengganti-Nya. Itu berarti manusia harus mampu memikul tanggung jawab besar dan mulia ini, yakni menjadi wakil Allah dalam menjaga dan mendamaikan alam semesta ini.

Dalam konteks pendidikan Islam, pendidikan bertanggung jawab terhadap pengembangan potensi manusia dalam melangsungkan kehidupan alam. Pendidikan menjadi tanggak bagi manusia untuk mampu memanfaatkan sumber daya alam, mengembangkannya untuk kemaslahatan kehidupan manusia. Kesempurnaan manusia harus menjadi cambuk untuk menghasilkan ilmu pengetahuan dan teknologi untuk kepentingan ummat manusia. Sebagai khalifatullah, manusia melalui pendidikan dituntut untuk mengembangkan segenap akan budi untuk kesejahteraan dan kedamaian dunia.

Di sinilah pendidikan Islam dipertaruhkan. Pendidiakn islam tidak hanya membangun kesalihan vertikal manusia dengan Tuhan, namun juga mengembangkan kesalehan sosial dan kesalehan lingkungan. Kesalehan sosial mengisyaratkan manusia untuk mampu membangun keharmonisan antar sesama, sedangkan kesalehan lingkungan mengisyaratkan untuk senantiasa menjaga alam dari 
kepunahan dan kerusakan. Keserakahan manusia yang tiada batas, terbukti telah menganggu keseimbangan alam, sehingga alam tidak mampu berfungsi dengan sempurna. Pendidikan islam mempunyai visi besar untuk menciptakan manusia trampil dan saleh. Baik kepada sesama maupun pada alam semesta.

\section{c. Menebarkan rahmat bagi semesta}

Berbicara tentang Islam, dua hal yang tidak bisa lepas darinya adalah Al-Qur'an dan Sunnah. Karena selain sebagai sumber ajaran, AlQur'an dan Sunnah merupakan ide-ide Tuhan yang termanifestasikan melalui teks. Yang mana, ide-ide Tuhan ini nantinya mampu menjadi "panduan" gerak dalam kehidupan manusia. Islam melalui teksnya telah menyatakan dirinya secara tegas dan jelas, bahwa tujuan diutusnya Muhammad sebagai penyampai risalah Islam, tidak lain adalah untuk menebarkan rahmat bagi semesta alam. Hal ini yang setidaknya termaktub dalam surat al-Anbiya' ayat 107:

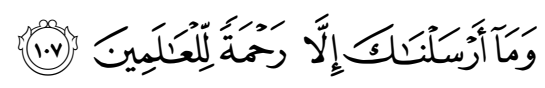

"Dan tiadalah kami mengutus kamu, melainkan untuk (menjadi) rahmat bagi semesta alam.: (Q.S. al-Anbiya':107)

Rumusan ini kemudian sering diverbalkan menjadi apa yang disebut tujuan risalah. Dengan kata lain tujuan risalah Islam tidak lain adalah untuk menebarkan rahmat untuk seluruh alam. Rahmat dalam kaitannya dengan hal ini, secara umum dapat kita artikan sebagai kelemah-lembutan, kedamaian, keadilan, cinta kasih yang membuahkan kebaikan bagi penerimanya. Sehingga risalah Islam ini harus mampu menjadi panduan dalam proses keberagamaan apapun, baik itu dalam hukum, muamalah, pendidikan, sosial bahkan politik. Tanpa bermaksud untuk melakukan simplifikasi, beberapa konsep rahmat yang tersebut di atas, kalau kita coba sederhanakan, tertampung dalam istilah yang sering digunakan dalam ushul fiqih sebagai mashlahat. Dalam hal ini mashlahat lebih dipahami sebagai "sistem nilai" yang menjadi kerangka dasar dalam prilaku keberagamaan (Misrawi, 2004:57). Kemaslahatan merupakan inti ajaran, dimana setiap segmentasi prilaku ummatnya harus diorientasikan pada prinsip kemashlahatan ini.

Pendidikan Islam dalam hal ini menjadi kawah candra di muka untuk membangun kemaslahatan dan rahmat bagi semesta. 
Berbagai fenomena konflik yang bersumbu pada perbedaan, baik itu perbedaan suku, agama, ras, bahasa, politik, aliran menjadi pijakan bagaimana pendidikan harus mengusung rahmat semesta dari Islam. Dengan kata lain, pendidikan Islam menjadi corong terdepan untuk mengajarkan dan membekali peserta didik dengan konsepsi rahmat untuk semesta. Sehingga output pendidikan Islam yang notabene menjadi bagian masyarakat mampu membangun harmoni dalam kehidupan. Pendidikan islam bukanlah wadah ekslusif yang melahirkan muslim-muslim fanatik, yang mudah menyalahkan dan menyesatkan orang lain. Namun lebih dari itu, muslim sejati adalah penebar rahmat bagi semua, tidak hanya bagi sesame muslim, namun semua makhluk di alam semesta ini.

\section{d. Menjadi agen penyempurna akhlak}

Salah satu hadits sahih yang diriwayatkan oleh Imam Bukhari; "Sesungguhnya aku (Muhammad) diutus untuk menyempurnakan akhlaq." (H.R. Bukhari) menegaskan bahwa keterutusan rasulullah, tidak lain adalah dalam rangka menyempurnakan akhlak yang mulia. Ini berarti bahwa ummat Islam sebagai ummat Rasulullah harus senantiasa menghiasi dirinya dengan karakter yang mulia. Berbagai kecenderungan demoralisasi yang melanda negeri ini adalah isyarat bagaimana akhlak merupakan hal yang urgen bagi kehidupan manusia.

Salah satu misi pendidikan secara umum adalah membangun sikap dan karakter peserta didik yang baik. Jika mengikuti taksonominya S. Bloom, pendidikan terkait erat dalam pembentukan afeksi (sikap), bukanhanya sekedar pengetahuan (kognisi) dan ketram-pilan (psikomotor). Pendidikan Islam yang merupakan derivasi dari nilai Islam, harus mampu mewujudkan tujuan kenabian dalam menyempurnakan akhlak ummat. Akhlaq dalam hal ini merupakan terminologi yang universal. Akhlaq merupakan implementasi suasana hati. Sehingga membangun akhlaq harus dimulai dari membangun hati. Akhlaq dalam tinjauan yang lain bisa disebut pula dengan karakter. Menguatnya wacana pendidikan karakter yang akhir- akhir ini sering dibicarakan, sesungguhnya menjadi momentum bagi pendidikan Islam untuk memproduksi karakter muslim yang tangguh. Sehingga produk pendidikan Islam 
nantinya benar-benar mampu menjadi kampium bagi implementasi karakter yang baik. Output pendidikan Islam harus mampu menjadi prototype manusia ideal bagi lainnya, bukan malah sebaliknya.

Empat hal tersebut kiranya menjadi dasar bagaimana filsafat pendidikan Islam memainkan peranannya dalam platform pendidikan Islam. Melalui filsafat Pendidikan Islam yang berbasis tujuan risalah dan hakekat pebciptaan, maka proses pendidikan yang dibangun di atasnya akan mengarah pada tujuan yang sama. Pada posisi ini, filsafat bukan lagi menjadi kajian pemikiran yang abstrak dan melangit, tapi benar-benar menjadi basis gerakan pendidikan Islam. Sebagaimana arti dari aksiologi it sendiri, bahwa ilmu harus mempunyai dimensi kegunaan dan kebermanfaatan bukan dalam artian sesuatu yang bebas sebebasnya, melainkan masih dalam kerangka tujuan risalah dan penciptaan manusia.

\section{Simpulan}

Filsafat merupakan induk dari ilmu pengetahuan. Secara umum, Filsafat dapat diartikan sebagai cinta kebenaran, sehingga tujuan dari filsasat adalah mencari kebenaran. Filsafat Pendidikan dapat dipahami sebagai pelaksanaan pandangan filsafat dan kaidah falsafah dalam pengalaman manusia yang disebut pendidikan. Disini filsafat pendidikan tidak bisa lepas dari filsafat secara umum. Filsafat Pendidikan Islam adalah landasan filosofis dalam implementasi pendidikan Islam. Dalam hal ini, filsafat pendidikan Islam harus berorientasi pada dua hal, yakni tujuan penciptaan manusia, yakni sebagai hamba dan sebagai khalifah. Kedua, tujuan risalah Islam, yakni menjadi rahmat bagi semesta dan menyempurnakan akhlak yang mulia. 


\section{DAFTAR PUSTAKA}

Ahmadi, 2005. Ideologi Pendidikan Islam. Yogyakarta: Pustaka Pelajar.

Arifin, Muzayin. 1994. Filsafat Pendidikan Islam. Jakarta: Bumi Aksara.

Barnadib, Imam. 1986. Filsafat Pendidikan. Yogyakarta: Andi Offset. Darwis, Djamaluddin. 2006. Dinamika Pendidikan Islam. Semarang: Rasail.

Jalaluddin dan Usman Said. 1996. Filsafat Pendidikan Islam. Jakarta: Karya.

Khun, Thomas S. 2000. The Structure of Scientific Revolution. Bandung: Rosda

Mas'ud dkk, Abdurrahman. 2011. Paradigma Pendidikan Islam. Yogyakarta: Pustaka Pelajar.

Misrawi (ed), Zuhairi. 2004. Menggugat Tradisi: Pergulatan Pemikiran Anak Muda NU. Jakarta: Kompas.

Mufid, Fathul. 2008. Filsafat Ilmu Islam (Buku Daros). Kudus: STAIN Kudus.

Muhadjir, Noeng. 2001. Filsafat Ilmu. Yogyakarta: Rakesarasin.

Nizar, Samsul. 2002. Filsafat Pendidikan Islam. Jakarta: RajaGrafindo. 
Hikmatul Mustaghfiroh

halaman ini bukan sengaja dikosongkan 